\title{
Legal Protection and Enforcement for Women Victims of Violence and Harassment
}

\author{
Sunnah \\ \{naibanjarutama05@gmail.com \} \\ Universitas 17 Agustus 1945 Jakarta
}

\begin{abstract}
The position of women in social life turned out to be out of alignment with men even though efforts in that direction had been long and continued. The strength of social, cultural and institutional factors that place women lower than men is the main cause of problems of violence and abuse. The formation of male dominance over women is viewed from the theory of nat ure and culture. In the process of transformation from nature to cult ure conquest often occurs. Men as culture have the authority to conquer and impose the will on women (nature). Violent crime is essentially a manifestation of human behavior. Actions against someone, especially women, which results in physical, sexual, psychological misery or suffering, and can also neglect the household, including threats to commit acts, coercion or deprivation of liberty against the law. the research questions can be formulated, namely, what are the factors that lead to violence and harassment, how the form of legal protection, and what obstacles are faced in an effort to provide legal protection for women who are victims.
\end{abstract}

Keywords: protection, legal, enforcement, women, victims

\section{Introduction}

In fact, the position of women in social life is not equal to that of men even though efforts in this direction have been made for a long time. The power of social, cultural and institutional factors that place women inferior to men is the main cause of that reality. Gender analys is always finds that some women experience subordination, marginalization, domination, and even violence. It was further mentioned that even at home women are not free from violence.

This was also experienced by women with the initials "RA", Former contract worker Assistant Expert Board of Trustees of the Manpower Social Security Organizing Agency (Dewas BPJS-TK), RA (27), together with their attorneys visited the Bareskrim Mabes Polri, Jakarta, Wednesday (2/2/2019). RA will file a case of a sexual crime he experienced with a suspected perpetrator from one of the BPJS-TK Dewis with the initials SAB. "Today, RA accompanied by his lawyer reported more or less what was thought to be related to obscene acts," said activist advocate for sexual crime victims, Ade Armando. Ade said, at this time RA with lawyers had entered thereporting stage. Then, it will be followed by a deepening investigation by the police.[1]. Furthermore, RA sexual harassment victims also filed a civil suit to the former Supervisory Board of the Social Security Employment Board (BPJS TK) Syafri Adnan Baharuddin (SAB), members of the BPJS TK supervisor board Aditya Warman, and Chairman of the BPJS Supervisory Board TK Guntur Witjaksono. RA's attorney, Heribertus S. Hartjodjoa, said his client filed a material and non-material lawsuit. 
For material RA filed a lawsuit of Rp. 3.7 million. Meanwhile the non-material lawsuit reached Rp1 trillion.[2].

From the Annual Notes on Violence Against Women in 2017 the number of reported cases increased by $74 \%$ from 2016 . The number of 2017 KTP cases amounted to 348,446 , this number jumped far compared to the previous year of 259,150. Most of the data comes from cases orcases handled by PN/PA. This data was collected from 3 sources namely; [1] 335,062 cases from the PN/ PA. [2] from the National Commision of Woman Right partner service institutions, there were 13,384 cases; [3] from the Service and Referral Unit (UPR), a unit that was intentionally formed by National Commision of Woman Right to receive complaints from victims who came directly to National Commision of Woman Right and (4) from the monitoring division that manages complaints coming in by mail and electronic mail. In the public sphere and community violence against women recorded 3,528 cases. $76 \%$ of violence against women in the Public or Community Domain is Sexual Violence namely Sexual Abuse (911), Sexual Harassment (704) and Rape (699). Meanwhile there were 343 cases of intercourse.[3].

Violence that befalls women can happen anywhere, in the public and private circumstances. This violence causes physical harmand some does not. Sexual haras sment is one of the violence that often befalls women because this abuse can occur any where. Sexual harassment (sexual harassment) was named in 1975. Previously the name had not yet appeared because the acts of harassment were still considered to be taboo until in the end until they became real. Sexual haras sment that occurs in the workplace is common, since it was established in 1975, the Equal Opportunities Commission (EOC) has noticed even sexual haras sment in the workplace. Over the years the commis sion has used its power under the Sex Discrimination Act (SDA) to support lawsuits against sexual harassment in labor courts to develop legal cases and have received attention on these is sues through campaigns and lobbying (Hunt, Davidson, Fielden, \& Hoel, 2007, p. 5).[4]

Violence and sexual harassment can also afflict anyone, any economic class, race, gender. When sexual harassment is seen as an issue of power rather than an issue of ass ault, a legal approach to lost is common, which places more emphasis on and emphasizes in appropriate sexual behavior. Fromfeminist responses, sexual harassment can occur due to unequal power relations, where women have an inferior position. The unequal power relations between men and women are not only seen from the physical form, but in general, this imbalance can also be seen from who holds power in the political, social, economic, and governmental environment, where men have a greater share bigger than women. Because the antidiscrimination law is more sensitive to the dynamics of this power problem, the antidiscrimination law is deemed appropriate to resolve the problem of sexual harassment compared to fort law. From feminist responses, sexual harassment can occur due to unequal power relations, where women have an inferior position. The unequal power relations between men and women are not only seen from the physical form, but in general, this imbalance can also be seen from who holds power in the political, social, economic, and governmental environment, where men have a greater share bigger than women. Because the antidiscrimination law is more sensitive to the dynamics of this power problem, the anti- 
discrimination law is deemed appropriate to resolve the problem of sexual harassment compared to fort law. Where the law of loss sees sexual harassment as an individual act aimed at women and it violates social norms and values, while the antidiscrimination law ass umes that sexual harassment is more abouteconomic coercion, or intellectual coercion. $\mathrm{E}$. H. Sutherland and Donald R.[5]. Cres sey, use criminology as a unit of knowledge and view crime as a social phenomenon. It means that criminology that observes crime of any kind is a social phenomenon, so the approach and countermeasures require sociological study.

The formation of the dominance of men overwomen in terms of the theory of nature and culture. In the process of transformation from nature to culture conquests often occur. Men as culture have the authority to conquer and impose their will on women (nature). Culturally men are placed in a higher position than women, because it has the legitimacy to conquer and coerce women. Fromthese two theories, the picture shows that sociocultural aspects have formed a social structure that is conducive to the dominance of men over women, thereby affecting individual behavior in life.[6].

The theory of the operation of law in society put forward by Chamblis and Seidman explains that the role of social forces in addition to influencing the people is part of the targets set for law but also influencing legal institutions. Seidman explained as follows:

a) All legal regulations provide an understanding of how a stakeholder must act. In relation to Violence and harassment, the role holder must carry out his role in order to protect victims from physical crime.

b) How the stakeholders will act as a response to the rule of law which is a functionof the legal rules directed at it, its sanctions. The activities of the implementing agency and the whole complex of social and political forces and others about him.

c) How the implementing agencies willact in response to the rule of law which is a function of the rule of law directed at them, their sanctions and the whole complex of s ocial, political and other regulations regarding themselves als o includes feedback that comes from the role holder.

d) How regulators willact, this is a function of the rules governing their behavior, sanctions, the whole complex of social, political, ideological and other forces that concern them also includes feedback coming from the stakeholders and the bureaucracy.

Violent crime is es sentially a manifestation of human behavior. Acts against a person, especially women, which results in physical, sexual, psychological, or physical misery or neglect of the household, inclu ding threats to commit acts, coercion or deprivation of liberty unlawfully. The main problem that needs attention is legal protection for women who are victims of violence. Based on the background and statement of the problemas described above, the research questions in this study can be formulated as follows:

1. What factors cause violence and abuse to women?

2. What is the form of legal protection for women who are victims of acts of violence and harassment?

3. What are the obstacles faced in efforts to provide legal protection for women victims? 
This study aims to encourage social change through law awareness and law making to create legalprotection for women against violence and sexual harassment.

\section{Method}

This journal is a normative legal research in which the approach used to address legal is sues is the statutory approach (statue approach) that examines the laws and regulations and international instruments concerned with protecting women in violence and harassment. Sources of legal materials us ed are primary legal materials and secondary legal materials. For primary legal materials and secondary legal materials, documentary and literature studies are conducted. Through the research process, analysis and construction of legal materials has been collected and processed.

\section{Result and Discussion}

\section{Theory of Role}

The role theory of Soerjono Soekamto[7] explains about: The dynamic as pect of the status (status) if a pers on carries out his rights and obligations according to his position, in another sense he is carrying out a role. "The role is a set of expectations imposed on individuals .

groups to carry out the rights and oblig ations that must be carried out by the stakeholders in accordance with what is expected by the community. Every person has a variety of roles that come from the patterns of social interaction. This also means that the role determines what it does for community and what opportunities are given by the community to him. According to Seorjono Soekamto, the role includes three things, namely:

1. The role includes norms that are connected with one's position or place in society. The role in this sense is a series of rules that guide someone in social life.

2. The role is a concept of what can be done by individuals in society as an organization.

3. Roles that can be said to be individual actors that are important to the social structure of society.

Role Theory describes social interaction in the terminology of actors who play in accordance with what is determined by culture, it is clear that what is meant by the role of law enforcement is more or less an effort made to make law, both in the narrow formal and in the broader material sense. The role as a code of conduct in every legal act, both by the legal subjects concerned and by law enforcement officials who are officially given the task and authority by law to ens ure the functioning of le gal norms that apply in social and state life

\section{Legal Protection Theory}

According to Locke, the people who carry out social contracts are people who are orderly and respect the freedom of the right to life and ownership of property as human rights. According to Locke the ideal society is a society that does not violate basic human 
rights.[8]

Furthermore, Locke said, theserights did not go to the authorities when the contract was carried out. Therefore, the power of the ruler granted through social contracts, by itself is not possible to be absolute. If so, the existence of such power is precisely to protect natural rights in question fromhazards that may threaten, both coming from within and from outside. That is, the law made in the state also has the duty to protect these basic rights. Basic rights commonly referred to as human rights, without distinction between one another. With these human rights, humans can develop their personal self, role, and contribution to the welfare of human life.

Fitzgerald explained about the theory of legal protection aimed at integrating and coordinating various interests in society because in one traffic of interest, protection of certain interests can only be done by limiting various interests on the other. The legal interest is to take care of human rights and interests, so that the law has the highest authority to determine human interests that need to be regulated and protected. Legal protection must look at the stages, namely legal protection born of a legal provision and all legal regulations provided by the community which basically constitutes the community's agreement to regulate the behavioral relationship between members of the community and between individuals with government who are considered to represent the interests of the community.

\section{Law Enforcement Theory}

Social problems (social problems) emerge as a modern disease and haunt everyone, for example dehumanistic acts of violence, looting, a sense of security that is very far from the side of human life, haras sment and sexual deviations that are increasingly trans parent. Violence, at least in recent years has become the most actual and very popular vocabulary in the midst of global civilization. Violence has entered into various areas of the community: political, economic, social, cultural, artis tic, ideological, religious thought, even in the most exclusive social areas named family or workplace. It is very ironic that in a modern society built on the principles of rationality, democracy and humanization, a culture of violence is increasingly becoming an inseparable phenomenon of life. Today we are clearly witnessing the rise in various crimes, moral damage, environmental destruction, poverty, rape, and sexual harassment. Everything is a culture of violence.

Violence is often seen as a social phenomenon outside of itself, not a serious problem because victims are weak women. This fact is reinforced by the stereotype (negative labeling) of society that women and children are weak creatures, therefore less able to be independent, must be regulated, led, and also educated. While men are strong, lead, regulate, educate women. If the perpetrators of violence against women and victims are men, it is considered an extraordinary act. The general public still regards violence against women as not a problem. Society is more accustomed to the tradition of tolerating violence against women and considers it normal because it is not yet fully sensitive in recognizing this problem, that violence has occurred against women and children, while the negativeimpacts 
have never been explained more deeply and absorbed by the community earlier.

However, this phenomenon is different from the teachings of applicable law, where the law must be implemented and enforced. How is that the law that must apply, basically not to deviate fiat yustitia et pereat mundus (even though the world collapses, the law must be upheld). The concept of law enforcement is embraced by the flow of legal positivism one of which is John Austin. In addition there is also law enforcement as the flow of pure law from Hans Kelsen, where he wants to cleanse the science of law from non-legal factors such as history, moral, sociological, political. Kelsen wants to accept the law as it is, namely in the form of regulations made and recognized by the State. Law enforcement through the Sociological flow of Roscoe Pound which views the law as a social reality, the law as a social control tool or known as the As a Tool of Social engineering.[9].

The formulation policy regarding violence against women contained in the International Instrument namely the Declaration on the Elimination of Violence against Women regulates the crime of violence ag ainst women, but this declaration further regulates what efforts are carried out by states, organs and $\mathrm{UN}$ agencies aimed at for the elimination of acts of violence against women. The policy on the formulation of violence again st women in the National Legal Instrument namely Law No. 23/2004 on the Elimination of Crimes in Domestic Violence, but only regulates criminal acts of violence against women within the scope of the hou sehold. Law Number 21 of 2007 concerning Eradication of Trafficking in Pers on Crimes against women, what if the crime of trafficking in person only. Furthermore, Provincial Government Regulations which are the Implementation of Protection of Victims of Violence on the bas is of Gender and Children are, among others, the Integrated Service Centers run by the Social Service for Women Empowerment and Child Protection (P2PA). The details are as follows:

I. Policy Formulation of Protection for Women in International Legal Instruments.

1. Convention On The Elimination Of All Forms Of Discrimination Against Women (CEDAW) Convention On The Elimination Of All Forms Of Discrimination Against Legal Is sues, Volume 47 No.3, July 2018321 Women (CEDAW) is a comprehensive convention that is `recognized in the world as a bill of Rights forWomen, because it emphasizes equality and justice between women and men, namely equality of rights and opportunities and the enjoyment of benefits in all areas of life and activities, equality in CEDAW is interpreted not as equality in all sectors but equality of treatment and opportunities in the political, economic, social, etc. (Patra, 2011) listed in Articles 1,2,3,5, and 6 .

2. Declaration on theElimination of Violence against Women This declaration on the Elimination of Violence against Women regulates the crime of violence against women, but this declaration further regulates what efforts are carried out by the state, organs and agencies of the United Nations that aim to eliminate violence towards women. Listed in Articles 1,2,3,4,5, and 6. 
II. Policy Formulation of Protection for Women in National Legal Instruments.

a. Legislation

1. The 1945 Constitution of the Republic of Indonesia

The 1945 Constitution of the Republic of Indonesia emphasizes the equality of rights between men and women in carrying out the protection of human rights not to distinguish men and women listed in Articles 28D, 28G, 28I, and 28J.

2. Law No. 8 of 1981 concerning the Criminal Code (KUHP)

Protection of women in Law No. 8 of 1981 concerning the Criminal Code (KUHP) only applies outside the scope of the household after Law No. 23 of 2014 concerning the Elimination of Domestic Violence. Violence against women is divided into 3:

a. Sexual violence in the absence of marital rape (acts of rape in marriage) listed in Article 285, 286, 288, 294, and 297.

b. Psychic violence listed in Articles 310 to 318

c. Physical violence listed in Articles 338, 306, 353, 354, 355, and 356. Material regulations are in the form of offense (regulations that regulate what constitutes crime and violation, elements of offense, and sanctions), which are regulated in the Criminal Code do not know gender based violence. This can be seen from the formulations of the article, for example: none of the articles recognize or identify violence against women; the articles relating to sexual crimes are categorized as crimes of decency and not crimes against the integrity of a woman's body.

3. Law Number 1 of 1974

Law Number 1 of 1974 has two characteristics, namely recognizing the legal capacity of women (wives), but on the other hand it actually reinforces the sex roles and gender stereotyping of women and men in rigidly dividing the roles of women in the private or domestic sectors. Weaknesses in this law have confirmed the sexual division of labor and stereotyping. Domestic violence, excessive workload and the non-recognition of women as family heads is a direct result of the sexual division of labor. Listed in Articles 1, 30, 31 and 33.

4. Law Number 8 of 1981 concerning the Criminal Procedure Code (KUHAP)

Criminal ProcedureCode is the basis of the statutory regulations for criminal law enforcement efforts carried out in a penal manner. Penalty effort (Sudarto, 1980) is one of law enforcement efforts or all actions taken by law enforcement apparatus which focuses more on eradication after the occurrence of crimes committed by criminal law, namely criminal sanctions which constitute a threat to the perpetrators. It is listed in Article 98 paragraphs 1, 184, and 183. As an example of a case of domestic violence theevidence is rather difficult to fulfill Article 184 due to the lack of witnesses, most of the witnesses are victims themselves. There is a need for evidence in the form of letters, in cases of domestic violence documentevidence in the form of post mortem that is made by a doctor. In this law there are at least 2 pieces of evidence, whereas usually cases of domestic violence occur in a house or a closed room that escapes the sight of others, witnes s testimony fromvictims and vis um et repertum can be used as evidence. (Peters on \& Bialo-Padin, 2012) 
5. Law Number 7 of 1984 concerning Ratification of the Convention Concerning the Elimination of All Forms of Discrimination Against Women.

Law number 7 of 1984 is a formof ratification of the Convention of Elimination of All forms of Discrimination Against Women (CEDAW) since 1984. This convention has been ratified by more than 177 countries and one of them is Indonesia. As a consequence of the ratification, the government of a country must implement efforts to eliminate various forms of discrimination against women. It is stated in Articles 15 and

16. Basically, the contents of the convention are in accordance with the Pancasila State and the 1945 Constitution, which stipulates that all citizens together with its position in law and government. The regulation of this convention does not affect the existing principles or legis lation because the existing laws and regulations contain the principle of equality between men and women as a manifestation of Indonesia's legal system that is already good and in accordance with the aspirations of the people. Violence against women apart from violating human rights also constitutes discrimination against women. (Moerti hadiati, 2010).

6. Law Number 30 Year 1999 concerning Human Rights

The sound of Article 3 of Law Number 30 of 1999 concerning Human Rights is emphasized in Article 4, Article 5, Article 20, Article 33 and Article 34. Article 4 of Law Number 39 of 1999 has the basis for establishing, among others, to protect, maintain and enhance human dignity in the need for recognition and protection of human rights. Without this, humans will lose their character and dignity, so that they can encourage other humans (homo homini lupus). Violence against women is an act that does not respect the rights of others. Article 45 emphasizes women's rights in the law are human rights.

7. Law Number 23 of 2004 concerning the Elimination of Domestic Violence.

The criminal law contained in the UUPKDRT is an administrative criminal law. Law Number 23 of 2004 Concerning the Elimination of Domestic Violence the articles described above constitute acts declared as criminal acts including physical violence Article 6, psychological violence Article 7, sexual violence Article 8 and also stipulates sanctions. Physical sanctions are in Article 44 sanctions, Article 45 regulates psychological sanctions while Article 46, 47, 48 regarding criminal sanctions for sexual violence. Additional criminal threats are in Article 50. Law Number 23 of 2004 does not only contain criminal provisions and various forms of domestic violence in the form of physical, sexual, psychological and neglect, but this law also regulates the rights victim's rights, protection for victims and also victims' recovery. Violence in the household is not considered as a personal matter whose scope is only in the household. Therefore, law number 24 of 2004 in chapter $V$ regarding the obligations of the government and the public is explained in Article 11.

8. Law Number 21 of 2007 concerning Eradication of Trafficking in Person Law No. 21 of 2007 concerning Eradication of Trafficking in Person Crimes against women, what if there is a crime of trafficking in person only. This law explains the violence in the form of physical violence, psychological violence, and deprivation of liberty, while sexual violence the explanation is sexual exploitation because it is more directed towards using victims, not just hurting. Law No. 21 of 2007 also facilitates victims to testify without the presence of victims by using audio. This is done. 


\section{Provincial Regulations}

The province is also the Organization for the Protection of Victims of Violence and Genderbased Abuse and Children, including the Integrated Service Center run by the Social Service for Women Empowerment and Child Protection (P2PA) In 2018 also noted a number of advances in the protection of women in acts of violence and harassment, including:

1. The creation of various policy products that have the potential to protect women from violence, including: the National Commission on Violence Against Women and LPSK related to the Protection of Witnesses and Victims for Cases of Violence against Women, Joint Agreement of 13 Ministries / Institu tions for "Implementing Integrated Management of Cases of Violence Against Women",

2. Judicial Review Verdict on Population Administration Law No. 23 of 2006 and Law No. 24 of 2013 concerning Population Administration for Occupants,

a. Supreme Court Regulation (Perma) Number 3 of 2017 concerning Guidelines for Judging the Cases of Women Who Are Confronting the Law,

b. Decision of the Constitutional Court Refusing Application for Extension of Adultery Article,

c. Ratification of Law No. 18 of 2017 concerning the Protection of Indonesian Migrant Workers (PPMI Law), Restitution Policy for Children who are Victims of Crimes, Expansion of Access to the Recovery of Women Victims of Childhood.

d. Another encouraging thing was when the South Jakarta District Court granted all the demands of a woman with a dis ability who suffered discrimination from the Etihad airline who took her off the plane because she was considered unable to save herself. The defendant must pay the loss suffered by the plaintiff in the amount of Rp.537 million due to the discriminatory act. This victory is a new breakthrough in the field of law in protecting people with dis abilities and the consistency of the government in implementing Law no.8 of 2016 concerning Person with Disabilities.

Although the is sue of violence against women has proven to be a serious social problem, it still lacks adequate res ponse, this is an obstacle in providing protection for women, because basically violence and harassment against women is understood only as a pers onal problem, meaning that if a woman being a target of violence, then directly related to personality, the victim is sought to do with the behavior of the victim is considered to trigger violence and know the harassment. This is similar to saying that, if women experience violence and harassment, it is thoughtto be more or less due to theirown share of mistakes. if the victim wants the handling of the problem that befell her, people assume that it can be resolved privately by the victim, at best the advice that is often received by women victims is to be resolved as a family, which actually means avoiding public handling, as well as legal settlement.

\section{Conclusion}

1. Violence / sexual harassment that occurs to a woman due to a system of values that places women as being weak and inferior to men; women are still placed in a position of subordination and marginalization that must be controlled, exploited and ens laved 
by men and also because women are still seen as second class citizens.

2. Practices in the implementation of law in the field there is sometimes a conflict between legal certainty and justice, especially when faced with the problem of violence and harassment, where alternative solutions are still emphasized peacefully and amicably, this is caused by the conception of justice is an abstract formula and does not really understand -it is really the limit of authority due to lack of guidance on the conduct of law enforcement while legal certainty is a normatively determined procedure, this is due to not really understanding the authority limits because of lack of guidance on the conduct of law enforcement.

\section{References}

[1] https://nasional.kompas.com/read/2019/01/02/14341491/korban-pentasan-seksual-dewasbpjs-enforce-report-report-or-des-course"Assistance Victims of Sexual Abuse BPJS

Employment Report Sus pected Perpetrators to Criminal Inves tig ation " , online 12-6-2019$09.00 \mathrm{WIB}$

[2] https://www.cnnindonesia.com/national/20190131153558-12-365433/korban-pelecedamsexual-gugat-eks-dewas-bpjs-tk-rp 1-trillion Victims of Sexual Abuse BPJS TK Ex-Rp 1,000 Trillion Online 12-6-2019-09.00 WIB

[3] the erosion of women's safe spaces in the vortex of populism, the record of violence against women in 2017, Komnas Perempuan 2018

[4] Hunt, C., Davidson, M., Fielden, S., \& Hoel, H. Sexual Haras sment in The Workplace: Literature Review. Manchester: Manchester Business School, University of Manchester, 2007, p.5

[5] Tong, R. P.Feminist Thought: The Most Comprehensive Introduction to the Mainstream of Feminist Thought. Westview Press, Colorado, 1998

[6] E. H. Sutherland and Donald R. Cress sey in Dr. Soerjono Soekanto, SH., MH., Hengkie Liklikuwata, SH., Drs. Mulyana W. Kusuma, An Introduction to Criminology, Gahlia

Indonesia, Jakarta 1981, p. 6

[7] Soejono Soekamto, Sociology An Introduction, PT Raja Grafindo Persada, Jakarta, 2002, p. 234

[8] Ibid,p. 244

[9] Roscoe Pound, An Introduction to the philosophy of Law, Yale Univers ity Press, New Heaven, 1954, p.4 